\title{
Grapevine breeding programs in Brazil
}

\author{
J.D.G. Maia' , U.A. Camargo'2, J. Tonietto³, M.C. Zanus³, \\ V. Quecini3, M.E. Ferreira ${ }^{4}$, P. Ritsche ${ }^{3}$
}

${ }^{1}$ Embrapa Grape and Wine, Tropical Viticulture Experimental Station, Jales, Brazil; ${ }^{2}$ Vino Vitis Consulting Ltda., Bento Gonçalves, Brazil; ${ }^{3}$ Embrapa Grape and Wine, Bento Gonçalves, Brazil; ${ }^{4}$ Embrapa Genetic Resources and Biotechnology, Parque Estação Biológica, PqEB, Brasília, Brazil

\subsection{Introduction}

\subsubsection{Grapevine: introduction and culture expansion in Brazil}

Grapes are not only one of the most produced fruit species worldwide; they are also among the earliest domesticated crops. The genus Vitis, to which the grapevine belongs, originated in North America and Eurasia and probably evolved before the breaking of the Bering intercontinental bridge in the Quaternary Period (Mullins et al., 1992). Vitis vinifera is the most popular viticulture species in the world, being the only one originated in Eurasia 65 millions of years earlier. Seeds of domesticated grapevines were already found in archaeological sites from the Neolithic Period in Europe (This et al., 2006). Grapes and wine are mentioned by Egyptians, Phoenicians, Greeks, Romans and Etruscans, among others, for medical and ritualistic purposes (Johnson, 1989; McGovern et al., 2009).

In the 1400s, grapevine ( $V$. vinifera) crops were introduced in the Canary and Madeira Islands and from there arrived to South Africa, Australia and South America. During the eighteenth century, the culture was introduced in North America via California. In contrast, hybrids between American species, such as Vitis labrusca and Vitis bourquina crossed to $V$. vinifera, started to be cultivated in the 1800 s and played an important role in the establishment of viticulture in America (Alleweldt et al., 1990; Hedrick, 1908, 1919).

In Brazil, the grapevine was introduced from insular Portuguese regions on the very first expedition with colonizing purposes. The first vineyards were established on the coast, where the state of São Paulo is currently (Figure 11.1) (Sousa, 1969). The Portuguese brought $V$. vinifera grapevine varieties, selected based on personal information and the experience of European growers (Miranda, 2001). However, Brazilian climatic conditions, especially on the warm and humid coast, were not favourable for European varieties. The first Brazilian wine was made around 1551, with grapes from vineyards established in Piratininga plateau, in the surroundings of the current city of São Paulo. In the Northeast region, there are notes about grapevine growing in the 1500 s in the state of Bahia, in the vicinity of the city of Salvador, 
around 1549 and in the state of Pernambuco as early as 1542 (Figure 11.1) (Sousa, 1969). Portuguese grape varieties, such as Ferral and Dedo de Dama, along with Muscat grapes, were also established in drier areas, averting the possibility of successive vintages (Salvador, 1627).

In the state of Rio Grande do Sul (Figure 11.1), the first viticultural activities were recorded only after the arrival of the Jesuit mission to Brazil in 1626, but those initial vineyards were completely destroyed when the religious order was expelled from the country. In the current state of Santa Catarina, records from 1807 mention the growing of grapes and other European fruits, probably introduced by natives from the Azores and Madeira Islands that migrated to Southern Brazil in 1700s. Those immigrants also re-established viticulture in the state of Rio Grande do Sul (Sousa, 1969; Miranda, 2001).

However, although widespread in colonial Brazil, viticulture was not a commercially important activity, and instead it was restricted to backyards in the cities and farmhouses in the countryside (Sousa, 1969). Some historians present several economic reasons to explain the lack of importance of Brazilian viticulture in that period (Dickenson, 1995; Sousa, 1969). Others assign the restricted success of the crop to biological and technological factors, such as the typical susceptibility of $V$. vinifera, the nonfavourable Brazilian climatic conditions and the limitation of agricultural management techniques at that time (Sousa, 1969).

The failure in growing European grapes in the New World is not restricted to colonial Brazil, as it has also been recorded in the history of North American agriculture.

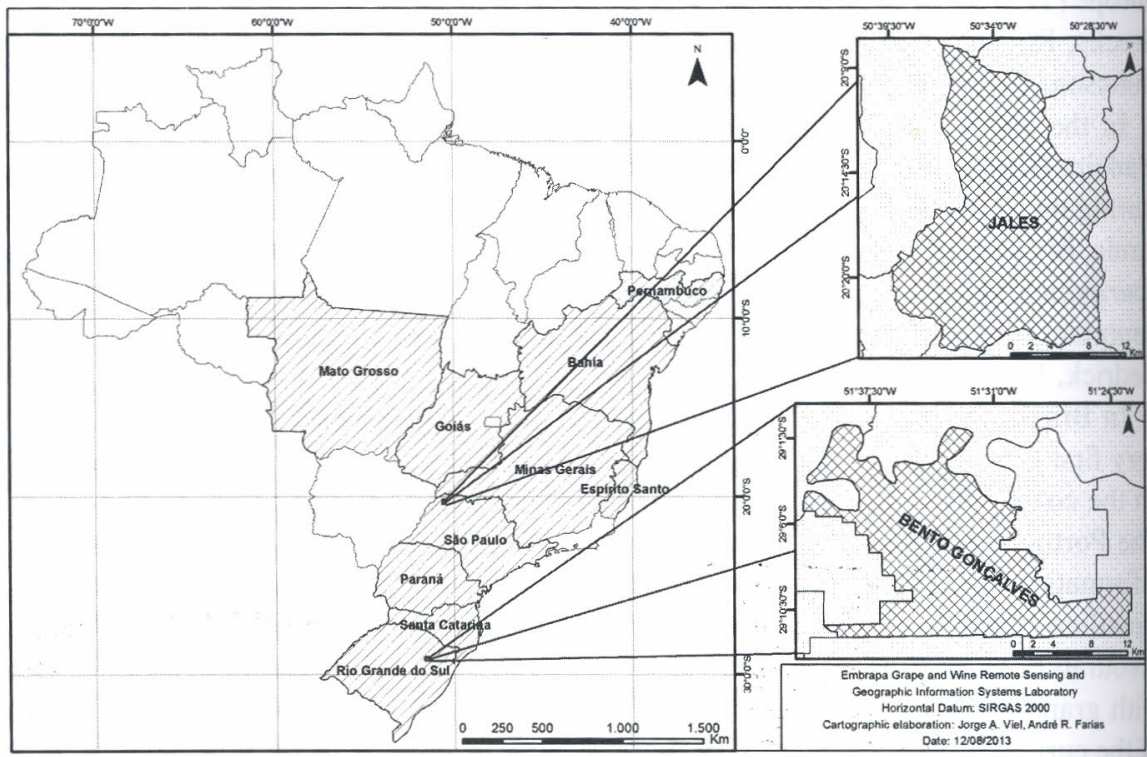

Figure 11.1 Map of the current viticultural regions in Brazil and the locations of Embrapa Grapevine and Wine Headquaters (Bento Gonçalves, RS) and Tropical Viticulture Experimental Station (TVES) (Jales, SP). 
The problems were only overcome with the incorporation of other Vitis species, native of North America, into commercial production. These grapevine species are hardier than the European varieties and started to be used from the nineteenth century, when the Americans developed the first hybrid varieties Catawba, Isabella, Norton, Ives and Concord (Hedrick, 1908, 1919; Pinney, 1989).

The spread of American grapes in Brazil gained momentum with the arrival of Italian immigrants, from 1875 on, resulting in a quick replacement of the European grapevine cultivars. However, as occurred in Europe, the introduction of American grape species brought along new fungal diseases, such as downy mildew (Plasmopara viticola (Berk and Curt) Berl.) and powdery mildew (Uncinula necator (Schw.) Burr). The phytosanitary problems contributed to compromise the cultivation of European and even of American grapevine cultivars known to be resistant to the major fungal diseases. Thus, new technological goals were established for Brazilian viticulture in order to prevent the occurrence of fungal diseases, including the development of cultivars with increased tolerance and the use of chemical control (Sousa, 1969). The adoption and evolution of those cultural practices contribute to the success of tropical viticulture in Brazil 100 years later.

Until the middle of the 1900s, Brazilian viticulture was restricted to the cultivation of American grapes under temperate and subtropical climates in the South and Southeast. After the spread of Isabella from 1830 to 1840, other American cultivars became popular, such as Herbemont, Concord, Ives, Seibel 2, White Niagara, Rose Niagara and Jacquez. In the 1970s, the Brazilian white wine market was supported by Seyve Villard 5276 and Couderc 13, while the red wines were mainly made from Ives (synonym: Bordô) and Concord (Camargo et al., 2012c).

\subsubsection{The current viticulture panorama in Brazil}

The development of synthetic fungicides allowed the widespread cultivation of European grapes in Brazil to fresh fruit and wine making markets. The cultivation of European grapes, such as the Italian cultivars Barbera, Bonarda, Peverella, Marzemino, Trebbiano and also Cabernet Franc, Merlot and Riesling, was encouraged by the government in Southern Brazil from the 1940s. However, the real dissemination of European cultivars occurred only in the 1970s, with the establishment of international companies in the state of Rio Grande do Sul. The initial Italian cultivars were almost completely replaced by French ones, such as Pinot Noir, Cabernet Sauvignon, Chardonnay, Gamay and Sauvignon Blanc to varietal winemaking (Camargo et al., 2012c; Protas et al., 2002).

In contrast, commercial tropical viticulture was started in the 1960s with the introduction of European table grapes in the Valley of São Francisco River, in tropical semiarid Northeastern Brazil (Protas and Camargo, 2011). Lately, the development of new cultivars adapted to local soil and climatic conditions, along with the improvement of viticultural practices, allowed the cultivation of American grapes in tropical areas. Thus, currently, one can witness the expansion of grapevine cultivation to tropical regions in Brazil, mainly to the states of Goiás, Mato Grosso, Pernambuco and Bahia (Figure 11.1) (Camargo, 2005; Guerra et al., 2005; Maia and Kuhn, 2001; Ritschel et al., 2008). 
In the Valley of São Francisco River (states of Pernambuco and Bahia), winemaking is based on traditional $V$. vinifera cultivars, such as Syrah, Alicante Bouschet, Chenin blanc and Moscato Canelli. Currently, new choices, such as Tempranillo, Petit Verdot, Touriga Nacional, Grenache and Verdelho, are spreading throughout the region. Several new Brazilian hybrid cultivars are increasingly being grown in both traditional and new viticulture areas (Camargo et al., 2012c).

Three periods of development of wine production have occurred since 1875, classified as First Generation - wines from American vines; Second Generation - wine diversification using hybrids and viniferas; and Third Generation - varietal wines. In the 1990s, Brazil entered the fourth stage (Tonietto and Mello, 2001), which involves the production of quality wines with Geographical Indications (GI). Since 1996, the Law of Industrial Property in Brazil (Law No. 9.279) paved the way for the recognition and legal protection of GI in two categories: GI and Appellation of Origin, at a nationwide level, under the authority of the Brazilian National Institute of Industrial Property.

In 1995, a small group of producers from the traditional Serra Gaúcha, a region in the surroundings of the city of Bento Gonçalves currently located at the Vale dos Vinhedos zone, became interested in having a GI for vinifera wines. In 2002, the region was recognized as the first GI in Brazil under the supervision of a growers association known as Aprovale. The development of the Vale dos Vinhedos GI resulted in several economic repercussions to wine production. From that point, other wine-producing regions became interested, resulting in several projects for GI development (Tonietto, 2012). In the Fourth Development Period of Brazilian winemaking, the recognized GIs, adding originality and value to the differential quality and typicality of products, are part of the conceptual and structural change strategies in sector policies for grape growers and wine producers to increase the competitiveness of Brazilian wines in national and international markets. The cultivars adapted to each region are valued for Brazilian regions with GIs, as in the case of the GI for Farroupilha (a county near Bento Gonçalves), with focus on muscatel vinifera-based wines due to the originality of the local production of cultivar Moscato Branco. Another example is the GI Vales da Uva Goethe, using American hybrid Goethe, which is traditionally cultivated in Santa Catarina.

Currently, Brazil is 13th worldwide in grape production (FAO, 2013). Despite the expansion tendency, Brazilian viticulture is still concentrated in the Central-southern regions of the country. The state of Rio Grande do Sul is the main producer, followed by Pernambuco, São Paulo, Paraná, Santa Catarina, Bahia and Minas Gerais (Figure 11.2). In 2012, 830,915 t, equivalent to approximately $57 \%$ of the national grape production, were industrialized to wine $(257,980,767 \mathrm{~L})$, juice $(70,066,733 \mathrm{~L})$ and other products, such as sparkling wine, dessert wine, concentrated must, and others (100,757,101 L) (Figure 11.3) (Mello and Machado, 2013). A large portion of Brazilian wine is made of grapes from American and hybrid cultivars. Although not accepted in Europe, these grapevines are broadly grown in Brazil, the US East Coast and Asia, due to the hardiness and yield of the plants. 
In the Valley of São Francisco River (states of Pernambuco and Bahia), winemaking is based on traditional V. vinifera cultivars, such as Syrah, Alicante Bouschet, Chenin blanc and Moscato Canelli. Currently, new choices, such as Tempranillo, Petit Verdot, Touriga Nacional, Grenache and Verdelho, are spreading throughout the region. Several new Brazilian hybrid cultivars are increasingly being grown in both traditional and new viticulture areas (Camargo et al., 2012c).

Three periods of development of wine production have occurred since 1875, classified as First Generation - wines from American vines; Second Generation - wine diversification using hybrids and viniferas; and Third Generation - varietal wines. In the 1990s, Brazil entered the fourth stage (Tonietto and Mello, 2001), which involves the production of quality wines with Geographical Indications (GI). Since 1996, the Law of Industrial Property in Brazil (Law No. 9.279) paved the way for the recognition and legal protection of GI in two categories: GI and Appellation of Origin, at a nationwide level, under the authority of the Brazilian National Institute of Industrial Property.

In 1995, a small group of producers from the traditional Serra Gaúcha, a region in the surroundings of the city of Bento Gonçalves currently located at the Vale dos Vinhedos zone, became interested in having a GI for vinifera wines. In 2002, the region was recognized as the first GI in Brazil under the supervision of a growers association known as Aprovale. The development of the Vale dos Vinhedos GI resulted in several economic repercussions to wine production. From that point, other wine-producing regions became interested, resulting in several projects for GI development (Tonietto, 2012). In the Fourth Development Period of Brazilian winemaking, the recognized GIs, adding originality and value to the differential quality and typicality of products, are part of the conceptual and structural change strategies in sector policies for grape growers and wine producers to increase the competitiveness of Brazilian wines in national and international markets. The cultivars adapted to each region are valued for Brazilian regions with GIs, as in the case of the GI for Farroupilha (a county near Bento Gonçalves), with focus on muscatel vinifera-based wines due to the originality of the local production of cultivar Moscato Branco. Another example is the GI Vales da Uva Goethe, using American hybrid Goethe, which is traditionally cultivated in Santa Catarina.

Currently, Brazil is 13th worldwide in grape production (FAO, 2013). Despite the expansion tendency, Brazilian viticulture is still concentrated in the Central-southern regions of the country. The state of Rio Grande do Sul is the main producer, followed by Pernambuco, São Paulo, Paraná, Santa Catarina, Bahia and Minas Gerais (Figure 11.2). In 2012, 830,915 t, equivalent to approximately 57\% of the national grape production, were industrialized to wine $(257,980,767 \mathrm{~L})$, juice $(70,066,733 \mathrm{~L})$ and other products, such as sparkling wine, dessert wine, concentrated must, and others $(100,757,101 \mathrm{~L})$ (Figure 11.3) (Mello and Machado, 2013). A large portion of Brazilian wine is made of grapes from American and hybrid cultivars. Although not accepted in Europe, these grapevines are broadly grown in Brazil, the US East Coast and Asia, due to the hardiness and yield of the plants. 


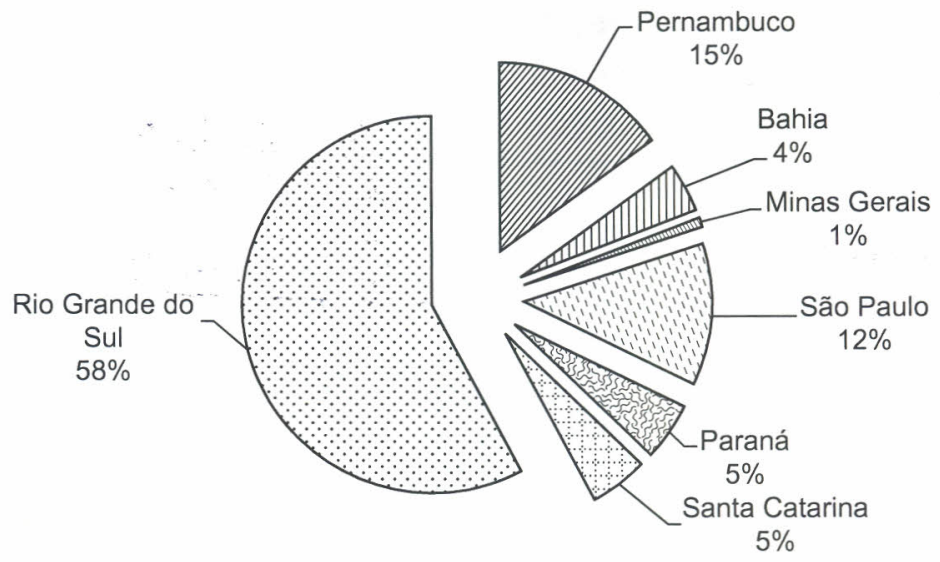

Figure 11.2 Grapevine production per state in Brazil. The most representative producing states are shown (Mello and Machado, 2013).

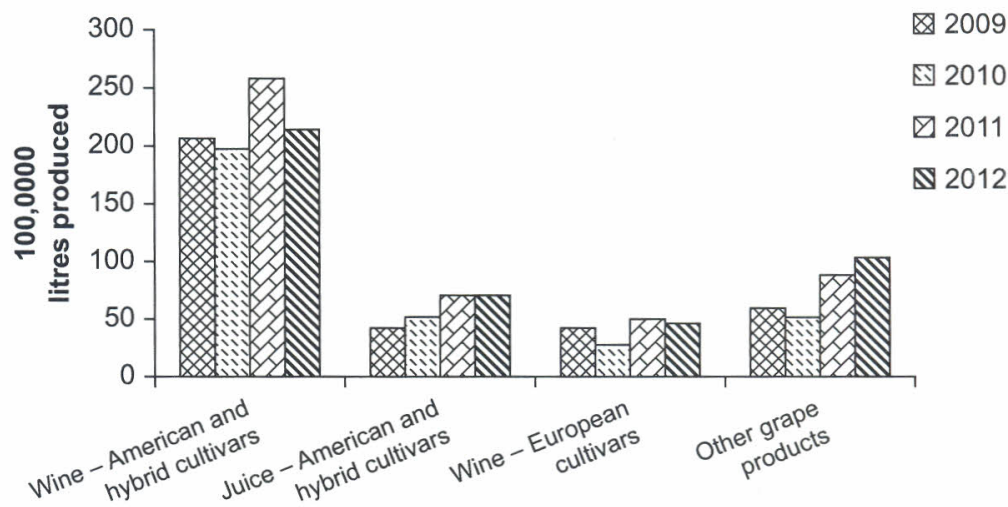

\section{Products}

Figure 11.3 Grape products in Brazil from 2009 to 2011. Other grape products include sparkling wine, dessert wine and concentrated must, among others (Mello and Machado, 2013).

\subsection{Germplasm banks}

In South America, public research institutions conserve grapevine genetic resources in independent collections. In Brazil, the Grapevine Germplasm Bank (GGB), maintained by Embrapa Grape and Wine, is currently the main collection in South America, consisting of approximately 1400 accessions, including cultivars, interspecific hybrids and wild species of Vitis and Ampelopsis genera (Table 11.1). Other ampelographic collections, with a smaller number of accessions, are conserved by several public grapevine research Brazilian institutions, such as agricultural research companies of the states of Minas Gerais (Empresa de Pesquisa Agropecuária de Minas Gerais, EPAMIG), São Paulo (Instituto Agronômico de Campinas, IAC), 
Table 11.1 Use of species of the Vitis genus in plant breeding during the last century and list of accessions from the Grapevine Germplasm Bank (GGB) at Embrapa Uva e Vinho

\begin{tabular}{|c|c|c|c|c|}
\hline \multirow[b]{2}{*}{ Species } & \multirow[b]{2}{*}{$\begin{array}{l}\text { GBB } \\
\text { accessions }\end{array}$} & \multicolumn{3}{|c|}{ Uses in breeding } \\
\hline & & Novel varieties & Rootstocks & $\begin{array}{l}\text { Interspecific } \\
\text { hybrids }\end{array}$ \\
\hline $\begin{array}{c}\text { Ampelopsis } \\
\text { cordata }\end{array}$ & 1 & - & - & - \\
\hline $\begin{array}{l}\text { Ampelopsis } \\
\quad \text { heterophylla }\end{array}$ & 1 & - & - & - \\
\hline $\begin{array}{l}\text { Ampelopsis } \\
\text { vitifolia }\end{array}$ & 1 & - & - & - \\
\hline $\begin{array}{l}\text { Interspecific } \\
\text { hybrids }\end{array}$ & 561 & $+++*$ & $++^{*}$ & $+++*$ \\
\hline $\begin{array}{l}\text { Non-classified } \\
\text { accessions }\end{array}$ & 52 & - & - & - \\
\hline $\begin{array}{l}\text { Muscadinia } \\
\quad \text { rotundifolia }\end{array}$ & 11 & ++ & $+*$ & + \\
\hline Vitis aestivalis & - & - & - & ++ \\
\hline Vitis ampelopsis & 1 & & & \\
\hline Vitis amurensis & 2 & + & - & ++ \\
\hline Vitis andersonii & 1 & - & - & - \\
\hline Vitis arizonica & 1 & - & - & - \\
\hline Vitis armata & 1 & - & - & $*$ \\
\hline Vitis berlandieri & 2 & + & +++ & - \\
\hline Vitis betulifolia & 1 & - & - & - \\
\hline Vitis bourquina & 12 & - & - & - \\
\hline Vitis candicans & 1 & - & + & -* \\
\hline Vitis caribaea & 2 & - & - & + \\
\hline Vitis caucasica & 1 & - & - & - \\
\hline Vitis champinii & 2 & + & + & - \\
\hline Vitis cinerea & 1 & -* & + & $++^{*}$ \\
\hline Vitis cordifolia & 1 & - & + & + \\
\hline Vitis coignetiae & 1 & - & - & $*$ \\
\hline Vitis davidii & 1 & - & - & - \\
\hline Vitis del rioi & 17 & - & $-* \ldots$ & _* \\
\hline Vitis doaniana & 3 & - & - & - \\
\hline Vitis embergerii & 1 & - & - & * \\
\hline Vitis flexиоsa & 1 & - & - & - \\
\hline Vitis gigas & 1 & - & - & $*$ \\
\hline Vitis girdiana & 1 & - & - & - \\
\hline Vitis hongijixin & 1 & - & - & - \\
\hline $\begin{array}{l}\text { Vitis } \\
\text { - jacquemontii }\end{array}$ & 4 & - & - & - \\
\hline
\end{tabular}




\section{Table 11.1 Continued}

\begin{tabular}{|c|c|c|c|c|}
\hline \multirow[b]{2}{*}{ Species } & \multirow[b]{2}{*}{$\begin{array}{l}\text { GBB } \\
\text { accessions }\end{array}$} & \multicolumn{3}{|c|}{ Uses in breeding } \\
\hline & & Novel varieties & Rootstocks & $\begin{array}{l}\text { Interspecific } \\
\text { hybrids }\end{array}$ \\
\hline $\begin{array}{r}\text { Vitis labrusca } \\
\text { and hybrids }\end{array}$ & 64 & $+++*$ & $++*$ & $+++*$ \\
\hline Vitis longii & 1 & + & ++ & - \\
\hline Vitis montícola & 2 & - & - & - \\
\hline Vitis novomexico & 1 & - & - & - \\
\hline Vitis piaseskii & - & - & - & $*$ \\
\hline Vitis riparia & 1 & $++*$ & $+++*$ & $+++*$ \\
\hline Vitis rupestris & 4 & $++^{*}$ & +++ & +++ \\
\hline Vitis romanetii ${ }^{\#}$ & - & - & - & $*$ \\
\hline Vitis rubra & 1 & - & - & - \\
\hline V. rupestris & 4 & - & - & - \\
\hline Vitis simpsonii & 1 & - & + & - \\
\hline $\begin{array}{l}\text { Vitis } \\
\quad \text { shuttleworthii }\end{array}$ & 1 & - & - & $*$ \\
\hline Vitis silvestris & 1 & - & - & - \\
\hline Vitis simpsonii & 1 & - & - & - \\
\hline $\begin{array}{l}\text { Vitis } \\
\qquad \text { sinocinerea }\end{array}$ & - & - & - & $*$ \\
\hline Vitis smalliana & 1 & - & - & $*$ \\
\hline Vitis slavinii & 1 & - & - & - \\
\hline Vitis thunbergii & 1 & - & - & - \\
\hline Vitis tiliifolia & 1 & - & + & - \\
\hline Vitis vinifera & 655 & $+++++*$ & $+*$ & $++++*$ \\
\hline Vitis vulpina & 1 & - & - & - \\
\hline $\begin{array}{l}\text { Vitis } \\
\quad \text { yeshanensis }\end{array}$ & 1 & - & - & - \\
\hline
\end{tabular}

Frequent usage is indicated by larger numbers of plus signs (+), whereas subtraction signs (-) indicate lack of use (adapted from This et al., 2006). The number of accessions at the GGB at Embrapa Uva e Vinho is presented in the GBB column. The species used by the local breeding program are represented by * and lost accessions are indicated by \#

Paraná (Instituto Agronômico do Paraná, IAPAR) and Santa Catarina (Empresa de Pesquisa Agropecuária e Extensão Rural de Santa Catarina, EPAGRI). The GGB at Embrapa Tropical Semiarid includes about 230 accessions and is the only collection kept in the Northeastern region of the country (Ferreira and Pádua, 2009).

\subsubsection{Grapevine germplasm bank}

GGB was initially assembled at the former Caxias do Sul Experimental station before Embrapa was founded. In 1975, upon the founding of Embrapa Grape and Wine, the collection contributed as a starting point for the development of the current GGB, formed by gathering smaller national grapevine germplasm collections and by the introduction 
of cultivars from several countries worldwide (Camargo, 1980). From the beginning, there has been a straight relationship between GGB and the Grapevine Breeding Program conducted at the institution. After evaluation, accessions introduced and maintained by the GGB can be directly used by growers and winemakers, also adding value to novel Brazilian GI. Alternatively, selected accessions presenting trait(s) of interest can be crossed to develop segregating populations and give rise to new cultivars. Table 11.1 summarizes the use of the germplasm, maintained by the Brazilian and other international collections, to develop new cultivars and form improved gene and genome banks for breeding purposes. A small part of the gene pool available in Vitis has been explored by breeders in Brazil and elsewhere.

\subsubsection{Strategies for the conservation of grapevine germplasm}

Grapevine germplasm comprises a large number of genotypes originated from environments with specific biotic and abiotic factors (This et al., 2006). The maintenance of grapevine collections in a uniform environment, safe from the occurrence of natural disasters, pest or disease attacks, is one of the greatest challenges of conservation. The maintenance of field grapevine collections requires extensive areas and large amounts of human and financial resources (Li and Pritchard, 2009). In contrast, in vitro conservation allows the maintenance of thousands of genotypes in small rooms, reducing the risks of extinction and genetic diversity losses (Walters et al., 2008; Volk, 2010; Bennelli et al., 2013). The advantages of in vitro culture include the higher propagation speed, the maintenance of fungus-, bacteria- and virus-free genotypes, small requirements for space, reduced costs per individual and the facilitation of germplasm transportation (Engelmann, 1991; Walters et al., 2008; Bennelli et al., 2013). In vitro conservation can also help the establishment of international agreements for germplasm exchange, mainly due to the improved phytosanitary conditions (Börner, 2006).

Until the end of the 1990s, the GGB was conserved in Bento Gonçalves, RS, in a region of temperate conditions $\left(29^{\circ} 09^{\prime} \mathrm{S}, 51^{\circ} 31^{\prime} \mathrm{W}, 680 \mathrm{~m}\right.$ high). Later, the bank was moved to the Tropical Viticulture Experimental Station (TVES), in Jales, SP, where the climate is classified as Aw Rainy Tropical with dry winters $\left(20^{\circ} 09^{\prime} \mathrm{S}, 50^{\circ} 36^{\prime} \mathrm{W}\right.$, $480 \mathrm{~m}$ high). Currently, GGB is maintained as two field collections. The germplasm that has been characterized is maintained by Embrapa Grape and Wine at the TVES in dense plots with four replicates per accession. The germplasm undergoing characterization under temperate climate conditions is maintained at the headquarters of Embrapa Grape and Wine, in Bento Gonçalves, as four to six replicates per accession, in the field, in a vertical conducting system, grafted on the rootstock 101-14 Millardet et de Grasset.

Approximately 1000 accessions are conserved in vitro as duplicates in minimal growth conditions at $21^{\circ} \mathrm{C}$ and propagated every 4 months. In vitro introduction and establishment for the remaining accessions of GGB is underway. Cryopreservation, at temperatures lower than $-196^{\circ} \mathrm{C}$, allows accessions maintenance for long times without phenotypic or genotypic modifications (Volk, 2010; Bennelli et al., 2013). Currently, cryopreservation protocols are available to a limited number of 
grapevine genotypes, including scions and rootstocks (Wang et al., 2000; Bennelli et al., 2003; Matsumoto and Sakai, 2003; Wang et al., 2003), some exhibiting up to $80 \%$ of recovery efficiency (Matsumoto and Sakai, 2003). However, until now, cryogenic preservation of grapevine genotypes is not routinely employed (Bennelli et al., 2013). At Embrapa Grape and Wine, plant recovery aftẹr cryopreservation of 11 genotypes is currently under investigation, employing modified vitrification and encapsulation dehydration protocols.

\subsubsection{Evaluation of GGB accessions}

For 10 years, 1000 accessions of the collection were evaluated in Southern Brazil under temperate climate conditions using 23 Biodiversity International descriptors (IPGRI, 1997). The following data were recorded: phenology (start and end of bud flushing, flowering, maturation and leaf fall); yield; must composition (soluble solids, titratable acidity (TA) and $\mathrm{pH}$ ); disease incidence (downy mildew, powdery mildew, anthracnose (Elsinoe ampelina (De Bary) Shear); viruses, grey mould (Botrytis cinerea, Pers.) and bunch rot (several agents)); features of cluster (size and shape) and berry (colour, shape, texture and flavour) and flower type (male, female or hermaphrodite). Data are available at Embrapa Grape and Wine webpage (Embrapa Uva e Vinho, 2009). Dried leaves of the accessions are kept in the herbarium.

Four hundred accessions are currently under evaluation in Bento Gonçalves, RS. Additionally, a sample of 200 accessions from the GGB was selected for traits associated to tropical adaptation, such as continuous growth, resistance to rust (Phakopsora euvitis Ono) and leaf blight, whose causal agent has not yet been determined and is currently under evaluation at the TVES, Jales (Camargo et al., 2012b). Berry total phenolics and anthocyanins are also being evaluated for the accessions (Caumo et al., 2012; Dall'agnol et al., 2013).

Genetic analysis of 1400 accessions from the GGB was initiated using $30 \mathrm{sim}$ ple sequence repeats (SSR) markers selected from the literature and multiplexed for three or more loci per amplification reaction. The set includes the six SSR markers described by This et al. (2004) and used for genetic studies of other grapevine collections worldwide. Thus, it will allow the confirmation of the trueness-to-type of GGB accessions. Therefore, genotyping is contributing to the current knowledge of the genetic variation in the collection and is resolving genetic identity issues. It also contributes to the selection of parents for future crossings, along with phenotypic evaluation data (Camargo et al., 2012a).

As a result of GGB evaluations, two new cultivars, Early Isabella and Concord Clone 30 (Early Concord) (Camargo et al., 2000; Camargo, 2004), somatic mutations of original Isabella and Concord and described elsewhere in this text, were propagated and made available to growers. Currently, molecular comparisons of regular cultivars and their respective sports are underway to confirm the clonal relations between them.

The results from molecular and morphological characterization of GBB accessions are offering support to the further development of Brazilian GIs. The region of Farroupilha, in the state of Rio Grande do Sul, concentrates more than $50 \%$ of the Muscat grape production in Brazil, including the cultivar Moscato Branco, one of the most 
cultivated Muscat varieties in the country. Also known as 'Moscato Italiano', the origin of Moscato Branco is not known, although it has been described in Brazil since the 1930s. Preliminary ampelographic data suggested that Moscato Branco is a variety with expressive commercial cultivation restricted to Brazil, since no Italian cultivar with similar traits has been identified so far. Agronomic and phenological features of Moscato Branco were also compared with other Muscat grapes maintained in the GGB. Similarly, multiplex panels of SSR markers were used to compare the genetic profile of Moscato Branco with 636 accessions from the GGB and 4.370 accessions from the French grape germplasm collection. The results indicated that Moscato Branco exhibits a unique genetic profile, distinct from Muscat blanc, Moscato Giallo, Moscato de Hamburgo and Moscato de Alexandria. Its DNA fingerprint is also different from accessions of the 'Malvasia' group, as well as from that of 'Italia' and its sports. These results confirm Moscato Branco uniqueness and are adding value and supporting the development of the GI for the Farroupilha region. The sequencing of the Moscato Branco genome using Next Generation Sequencing technology was initiated to increase the knowledge on the genome context of the genotype, aiming the development of molecular tools to support further research on grape breeding and genetics in Brazil (Martins et al., 2013).

\subsection{Brazilian grapevine breeding programs}

The first notes on grapevine genetic breeding in Brazil were about private initiatives from the late nineteenth century (Paz, 1898; Sousa, 1969). In the 1940s, public institutions began these activities, first in the state of São Paulo and later in Rio Grande do Sul (Santos Neto, s.d.; Santos Neto, 1971; Sousa, 1969; Pommer, 1993; Camargo et al., 2009).

\subsubsection{IAC breeding program}

The grapevine breeding program maintained by IAC is a landmark for the beginning of the development of cultivars adapted to tropical climates. Several table grape cultivars, such as Piratininga and Patricia, fundamental to the development of tropical viticulture in São Francisco River Valley (Soares and Leão, 2009), were developed by the program.

However, the main results of the program were the development of rootstocks adapted to tropical conditions (Santos Neto, 1971). Those genotypes have been widely used in tropical viticulture with $V$. vinifera and American scions (Soares and Leão, 2009; Kuhn et al., 2003; Guerra et al., 2005; Regina et al., 2006). Rootstock IAC 313 (synonym: Tropical) was very important in the establishment of viticulture in the Valley of the São Francisco River and has also been used in the north of the state of Minas Gerais and in the Northwest of São Paulo. IAC 572 (synonym: Jales) is currently the most popular rootstock onto which American grapevines are grafted in tropical areas in Brazil. Another choice for tropical climates is IAC 766 (synonym: Campinas). 
The fast spread of those rootstocks developed to warmer areas, virtually replacing the traditional rootstocks from temperate regions, is a proof of the great contribution of grapevine breeding programs to tropical viticulture (Camargo, 2002). The current tendency is the increasing usage of these rootstocks, along with the spread of tropical viticulture in Brazil (Camargo, 2008).

Regarding wine grapes, the program has developed the cultivars Rainha (IAC 116-31) and Máximo (IAC 138-22), interesting commercial choices for the states of São Paulo and Espírito Santo, where they are currently employed to make white and red 'vinifera'-type wines, respectively. The cultivation areas of those cultivars have remained stable in the country (Camargo, 2008).

\subsubsection{Máximo (IAC 138-22)}

Máximo is a hybrid producing red grapes, resultant from the cross between Seibel 11342 and Syrah, made by IAC researchers in 1946 in the state of São Paulo (Sousa and Martins, 2002). It is cultivated in São Paulo, Jundiaí and São Roque counties and also on the mountain regions of the state of Espírito Santo. There are records of its cultivation and use in winemaking also in the south of Brazil (Sousa and Martins, 2002). It is an early material, tolerant to the main grapevine diseases in Brazil (Gallo Neto, 2008; Pommer, 2009). It can be successfully grafted on IAC 313 and IAC 766 rootstocks (Terra et al., 1990). It can reach yields up to $30 \mathrm{t} / \mathrm{ha}$, with soluble solids and TA of $16^{\circ}$ Brix and $150 \mathrm{meq} / \mathrm{L}$, respectively (Embrapa Uva e Vinho, 2009). Máximo wine is distinguished by its deep characteristic colour and high acidity (Camargo and Maia, 2008; Sousa and Martins, 2002).

\subsubsection{Rainha (IAC 116-31)}

Rainha is a cultivar producing white grapes, a hybrid from the cross of Seibel 7053 and Burgunder Kastenholtz made in 1946 at IAC in the state of São Paulo (Sousa and Martins, 2002; Pommer, 2009). Currently, it can be found in the states of São Paulo, Santa Catarina and also on the mountain regions of Espírito Santo. The growth area of the cultivar in those states remains stable, showing no trend towards increase or reduction (Camargo, 2008; Camargo and Maia, 2008). The genotype is distinguished by its medium vigour and harvest in late January (Sousa and Martins, 2002). Soluble solids are typically around $22^{\circ} \mathrm{Brix}$ and TA is $96 \mathrm{meq} / \mathrm{L}$ (Embrapa Uva e Vinho, 2009). The white wine made with Rainha is pleasant and well-balanced. It can be used as a blend in red wines (Pommer, 2009).

\subsubsection{Embrapa Grape and Wine breeding program}

Embrapa Grape and Wine conducts a grape breeding program mainly focused on hybridization aiming to develop novel grape cultivars for in natura consumption and processing for the wine and juice industries (Ritschel and Maia, 2009). Despite the existence of specific lines of interest for each usage, the program has common goals, such as the development of novel cultivars with greater fecundity in warm conditions and/or increased tolerance to the major grapevine pests and diseases. Specific 
objectives for each product are also pursued. Concerning the development of wine grapevine cultivars, the program pursues three main objectives: for $V$. vinifera grapes, the main purposes are the development of novel white Muscat cultivars with resistance to bunch rot and red grape cultivars to give rise to wines with intense colour. The development of novel grape cultivars totally adapted to tropical conditions in order to make truly 'labrusca'-type wines is also a goal, since the Brazilian market favours this type of wine. Finally, one of the main interests is to develop cultivars displaying the hardiness of American grapes and the flavour of $V$. vinifera.

Basic germplasm used by the program includes $V$. vinifera and hybrids from $V$. labrusca, along with tropical wild species such as Vitis caribaea, Vitis gigas, Vitis smalliana and Vitis schuttleworthii. Complex, interspecific hybrids obtained in Europe after phylloxera dissemination (e.g., Seibel and Seyve Villard, among others) and resulting from crosses between $V$. vinifera and several American species, such as Vitis rupestris, Vitis riparia, Vitis aestivalis, Vitis cinerea, Vitis berlandieri, V. bourquina and $V$. labrusca, are also used by the program, mainly as source of resistance genes for the most important diseases and pests (Table 11.1) (Camargo, 1998).

Evaluations are performed at TVES located in Jales, in the Northwest of the state of São Paulo. During initial selection, the features carefully considered include resistance to the main diseases, especially downy ( $P$. viticola) and powdery mildew ( $U$. necator), flower bud fecundity, yield, sugar content, acidity and flavour. Colour intensity is also taken into consideration in selections of grapes for red winemaking.

About 1000 hybrids, resulting from crosses between the before mentioned species and with the purpose of developing novel wine cultivars, are evaluated each year. Chosen individuals are propagated to selection fields, where they are evaluated for two to three years. Promising selections are then propagated to validation fields, where their performances are evaluated further for 3-4 years. The evaluation step includes sensory analysis of the wine made at a microscale. Advanced selections are subsequently tried on growers' fields for about 2 years. Novel cultivars are released in accordance to the growers' evaluations.

Recently, three novel wine grape cultivars displaying the $V$. vinifera flavour and the hardiness of American grapes and hybrid grapes were developed and released by Embrapa Grape and Wine. Seven new 'labrusca'-flavour, double-purpose cultivars for juice and wine were also released. High yields and tolerance to the main grape diseases, such as downy and powdery mildew, are the main features of those cultivars. Hybrids from crosses between $V$. vinifera accessions are still under evaluation. For the development of white grapes, progenies are resulting from different combinations of the following cultivars: Muscat Frontignan, French Colombard, Moscato di Hamburg, Green Malvasia, Moscato di Canelli, Palomino, Moscato di Alexandria, Petit Manseng and Muscat Frontignan. For the red ones, hybrids were generated using Cabernet Franc, Alicante Bouschet, Tannat and Merlot.

\subsubsection{Hardy hybrids with V. vinifera flavour}

Two novel, white-grape producing, interspecific hybrids were released by Embrapa Grape and Wine with the purpose of making aromatic white wines: Moscato Embrapa in 1997 and BRS (which identifies all new materials [including cultivars] released by Embrapa) 
Lorena in 2001. The main objective was to develop a hybrid grapevine for standard wines, indistinguishable from those made with $V$. vinifera cultivars, to offer an alternative to vinifera-like products with high quality and competitive prices. Both cultivars present high yields, high sugar levels and good tolerance to the main diseases. Thus, they have quickly spread throughout the state of Rio Grande do Sul. They have been well-accepted by growers, due to their agronomical qualities, and by consumers, due to the balanced flavour and Muscat-like characteristics of their wines (Camargo, 2008). In 2011, the state of Rio Grande do Sul processed approximately 7.700t of BRS Lorena and 11.200t of Moscato Embrapa, confirming the significance of those cultivars (Mello and Machado, 2013). With the same purpose, the red grape cultivar BRS Margot was released in 2007. It consists of an interspecific hybrid for red winemaking with sensory properties indistinguishable from those of $V$. vinifera wines along with low production costs. BRS Margot is currently under dissemination at Serra Gaúcha, and it is an interesting alternative to compete with lowprice, imported wines in Brazil. Due to its high tolerance to the main diseases, the cultivar has the potential to be employed in organic production systems (Camargo, 2008).

\subsubsection{Moscato Embrapa}

Moscato Embrapa (Camargo and Zanus, 1997) is a Muscat white grape, obtained from the cross between Couderc 13 and July Muscat, made in 1983. The hybrid was selected in 1990. From 1991 on, the selection has been propagated in semicommercial scale and evaluated by growers, winemakers, wineries and growers' cooperatives. It was released in 1997.

Plant vigour and flower bud fecundity are high, with an average of two clusters per cane. It also displays a high level of bud flushing; thus, it requires green pruning practices to allow light penetration in the vegetative canopy. The recommended spacing ranges from 2.5 to $3.0 \mathrm{~m}$ between lines and $1.8-2.5 \mathrm{~m}$ between plants on the rootstocks 101-14 Millardet et de Grasset or Paulsen 1103. The recommended pruning system is mixed, and the most effective conduction system is the pergola system, where it can reach yields up to $35 \mathrm{t} / \mathrm{ha}$. The reaction to downy mildew is similar to that of the cultivar Isabella, but it is susceptible to anthracnose. It is tolerant to powdery mildew and to grey mould.

The berries are light green with semifleshy pulp and Muscat flavour. Average soluble solids is $19^{\circ}$ Brix and TA varies from 90 to $100 \mathrm{meq} / \mathrm{L}$. The wine has a light yellow colour, intense aroma, with a light Muscat flavour, low acidity and medium or long aftertaste, which is preferred by Brazilian consumers.

Moscato Embrapa is classified as a cultivar of the late group, it is recommended to be grown in the region of Serra Gaúcha region for white table wine that is typically aromatic with low acidity. Although it was originally developed to be grown under temperate conditions, it has also been successfully grown in tropical areas.

\subsubsection{BRS Lorena}

BRS Lorena (Camargo and Guerra, 2001) is a white Muscat grape, resulting from a cross between Malvasia Bianca and Seyval made in 1986. It was grafted in 1990, in Bento Gonçalves, and selected for its performance to be cultivated in the region of 
Serra Gaúcha. Among its qualities, the proper growth vigour for the region, the potential for high yields, good tolerance to the main grapevine diseases and also for high soluble solids and balanced acidity can be mentioned. It started to be propagated in Serra Gaúcha in a semicommercial scale in 1994. In the following years, those initial observations were confirmed, and the cultivar was released in 2001.

It presents medium vigour and high fecundity of buds, except for the basal ones, thus, long pruning is recommended. The growth habit is erect, showing proper adaptation to vertical systems and to pergola. The recommended rootstocks are 1103 Paulsen and 101-14 Millardet et de Grasset and spacing ranges from 2.5 to 2.8 between lines and 1.5 between plants. BRS Lorena has high-yield potential, reaching up to 25-30 t/ ha. The cultivar also presents a good reaction to the main grapevine diseases, with few occurrences of anthracnose, grey mould and powdery mildew. It displays medium susceptibility to downy mildew. In rainy years, it may exhibit losses caused by the ripe grapes rot (Glomerella cingulata (Ston.) Sapuld and Schrenk).

Berries are green-yellowish, with resistant peel, fusing pulp and Muscat flavour. The grapes easily reach $20-21^{\circ} \mathrm{Brix}$ and TA is between 100 and $110 \mathrm{meq} / \mathrm{L}$. Two different wines can be made with the grapes of BRS Lorena, a table white wine and a sweet sparkling wine. The white wine made by the classical system exhibits the following chemical characteristics: $\mathrm{pH} 3.4$, TA of $\approx 80 \mathrm{meq} / \mathrm{L}$ and dry extract about $20 \mathrm{mg} / \mathrm{L}$. The wine colour is straw-yellow, with greenish reflections, a light and delicate pronounced aroma, a medium Muscat-like flavour and a complex taste that can be described as balanced and complemented by the delicate and lingering aftertaste. It is suitable for consumption from bottling up to 24-36 months, depending on storage conditions. The differential winemaking of BRS Lorena grapes results in a white wine with greater antioxidant content, in comparison to regular white wines (Camargo, 2008).

The sweet sparkling wine made from BRS Lorena has a sugar content of $60 \mathrm{~g} / \mathrm{L}$ and carbonic gas pressure of $4 \mathrm{~atm}$, at $20^{\circ} \mathrm{C}$. The sweet sparkling wine is straw-yellow in colour, with greenish reflections; it presents good foam and persistent perlage, an excellent aroma that can be described as pleasant and delicate, mixed with the floral varietal trait and the proper level of acidity, along with carbonic gas effects. It has a delicate and pleasant taste with fruit notes and is able to retain its sensory qualities for up to 24 months from bottling.

BRS Lorena is an early Muscat grape cultivar recommended to Serra Gaúcha for white and sparkling winemaking. It has also been successfully evaluated in tropical regions and organic systems.

\subsubsection{BRS Margot}

BRS Margot (Camargo and Guerra, 2007) is a cultivar producing red grapes obtained from the crossing between Merlot and Villard Noir made in 1977 at Embrapa Grape and Wine. Its pedigree consists of $74.22 \% \mathrm{~V}$. vinifera genomic context and $25.78 \%$ from other species $(14.84 \% \mathrm{~V}$. rupestris, $4.69 \% \mathrm{~V}$. aestivalis, $3.52 \% \mathrm{~V}$. labrusca, $1.95 \% \mathrm{~V}$. riparia and $0.78 \% \mathrm{~V}$. cinerea). The genotype was selected in 1995 for its yield, sugar contents and resistance to the main fungal diseases. From 2003 to 2005, it was evaluated under commercial scale production systems, confirming the initial 
observations. The cultivar was released in 2007. BRS Margot presents high fecundity of flower buds, including the basal structures. Yields of the cultivar are up to 25-30 t/ ha. The berries display soluble solid contents of $20-21^{\circ} \mathrm{Brix}$, TA of $\approx 90 \mathrm{meq} / \mathrm{L}$ and average $\mathrm{pH} 3.30$. It tolerates the main fungal diseases, especially powdery mildew and grey mould.

The wine made from BRS Margot has sensory features of a typical $V$. vinifera wine with no detectable 'foxy' flavour. It can be used in blends in hybrid-type wines, contributing to the alcoholic content, besides representing an alternative to reduce the costs of $V$. vinifera-winemaking (Ritschel and Sebben, 2010). In the vintages 2004, 2005 and 2006, BRS Margot was used to make a red wine in semicommercial scale at Embrapa Grape and Wine (Camargo and Guerra, 2007). The main features of the average chemical composition of the wines are shown in Table 11.2. The key sensory characteristics of these wines are the visual aspects (ruby-red colour with violet reflections). In the end of 2006, it was observed that the violet hue turned to brownish-orange in the wine made in 2004, which indicates a good durability potential. It has an average intensity of aroma and it is delicate, resembling wild berries (cherry, blackberry and currant). A 'foxy' or bitter taste is absent; the aftertaste is balanced and pleasant. It is suitable for young wines, with the potential to be consumed up to three years after elaboration. BRS Margot is recommended to be cultivated in the South of Brazil, under temperate conditions, to be used in red vinifera-like winemaking.

\subsubsection{Forthcoming selections}

Currently, approximately 20 selections for winemaking are under evaluation, and two advanced selections are under validation in growers' areas in the south of Brazil and in tropical regions, supporting the perspective of the release of novel grapevine cultivars for wine making in the forthcoming years. The advanced selections produce white Muscat berries with fusing pulp. The selection under testing in the south of Brazil is tolerant to bunch rots (acid rot and grey mould). The cluster is cylindrical-conical in shape with shoulder, medium in size and has loose berries. The must composition is $23.6^{\circ}$ Brix with TA of $115 \mathrm{meq} / \mathrm{L}$ and $\mathrm{pH} 3.3$. The wine, resulting from winemaking at microscale, presents alcohol contents of $14.2 \%$, reducing sugar of $2.3 \mathrm{~g} / \mathrm{L}$ and TA of $106.1 \mathrm{meq} / \mathrm{L}$ with a $\mathrm{pH}$ of 3.2. It has a straw colour and gives rise to a clear wine with intense Muscat aroma, reminiscent of papaya and cloves, with lower acidity and a sweet attack. The flavour exhibits high persistence and no defects of bitterness or astringency. The other grapevine selection is tolerant to grey mould but susceptible to acid rot. The cluster is more compact than that of the first selection. Must exhibits $20.1^{\circ} \mathrm{Brix}$, TA of $103 \mathrm{meq} / \mathrm{L}$ and $\mathrm{pH} 3.3$. The chemical composition of the wine consists of $12.9 \%$ alcohol, reducing sugar contents of $4.5 \mathrm{~g} / \mathrm{L}$, TA of $83.8 \mathrm{meq} / \mathrm{L}$ and $\mathrm{pH} 3.4$. The wine is clear, light straw-green in colour, with a fine aroma of vinifera wine, medium intensity, delicate and slightly fruity. It tastes fresh and balanced, displays correct acidity and is considered harmonious, with no defects of bitterness or astringency. It is described as having medium persistence. 
Table 11.2 Physicochemical parameters of 'BRS Margot' wine (Camargo and Guerra, 2007)

\begin{tabular}{|c|c|c|c|c|c|c|c|c|}
\hline $\begin{array}{l}\text { Must yield } \\
(\%)\end{array}$ & $\begin{array}{l}\text { Alcohol } \\
\left({ }^{\circ} \mathrm{GL}\right)\end{array}$ & $\begin{array}{l}\text { Total acidity } \\
(\mathrm{meq} / \mathrm{L})\end{array}$ & pH & $\begin{array}{l}\text { Reduced dry } \\
\text { extract }(g / L)\end{array}$ & $\begin{array}{l}\text { Anthocyanins } \\
(\mathrm{g} / \mathrm{L})\end{array}$ & $\begin{array}{l}\text { Colour } \\
\text { (intensity) }\end{array}$ & $\begin{array}{l}\text { Total } \\
\text { polyphenols }\end{array}$ & $\begin{array}{l}\text { Total } \\
\text { tannins } \\
(\mathrm{g} / \mathrm{L})\end{array}$ \\
\hline 70.00 & 12.04 & 70.00 & 3.52 & 21.35 & 465.20 & 0.50 & 37.30 & 1.64 \\
\hline
\end{tabular}




\subsubsection{Dual purpose 'labrusca' or strawberry flavoured hybrids (wine and juice)}

Grapes with 'labrusca' (typical strawberry) flavour are the greatest group of novel cultivars released by Embrapa Grape and Wine. They can be used for juice and wine production, thus being considered double purpose. Five of those cultivars were obtained from crosses, and all of them gave rise to wines and juices with intense purple colour, appreciated by Brazilian consumers. Moreover, they present distinct productive cycles and, with the exception of BRS Rúbea, have high sugar contents. In contrast, Concord Clone 30 (Early Concord) and Early Isabella were obtained from clonal selections. They were introduced and evaluated by the GGB in order to confirm the distinct phenological behaviour in comparison to that of the original cultivars, Concord and Isabella. The cultivars are spreading throughout Serra Gaúcha because their features meet the demands of several wineries, which recommend them to the growers to expand the harvesting and processing periods by the combined use of early and late cultivars (Figure 11.4) and also to improve the quality (colour, sugar/alcohol) of the wines and juices made from traditional cultivars (Camargo, 2008).

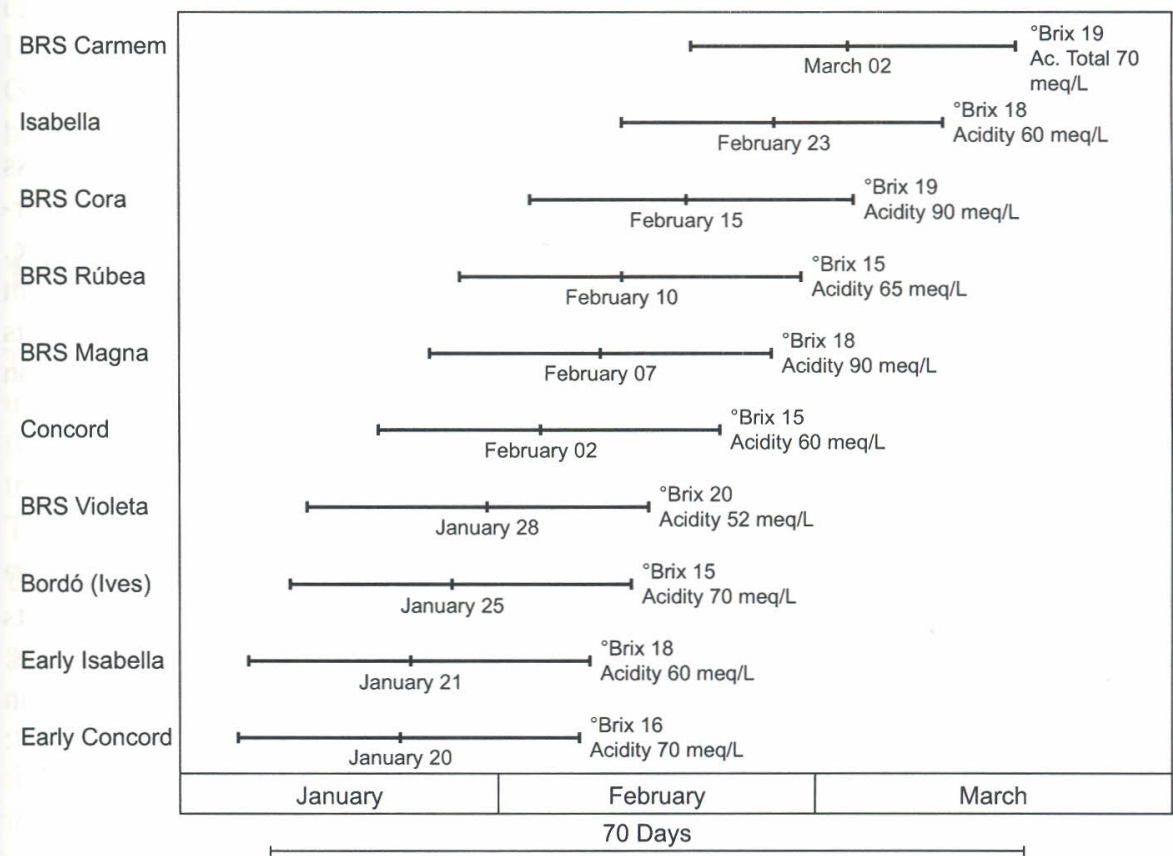

Figure 11.4 Must composition and harvesting period under temperate climate conditions of Brazilian hybrid grapevine cultivars exhibiting 'labrusca' or 'strawberry' flavour. The berries from the cultivars are considered dual purpose, i.e. wine- and juice-making. It is noteworthy that novel cultivars exhibit an extension of approximately 40 days in the harvesting period under temperate conditions, in comparison to the harvesting period of traditional cultivars (Isabella, Concord and Bordô/Ives). The extended harvesting allows better distribution of the labour force and facility resources in the vineyard and winery (Ritschel et al., 2012). 


\subsubsection{BRS Rúbea}

BRS Rúbea (Camargo and Dias, 1999), obtained from a cross between Rose Niagara and a plant from a seed of Ives, is a typical teinturier red grape, for primary use in juice blends with Isabella and Concord. It can also be used to make 'labrusca'-type wines. The cluster is small, $100 \mathrm{~g}$ on average, the berries length is $19 \mathrm{~mm}$ in average and $15^{\circ}$ Brix. The plants are vigorous, disease resistant and well-adapted to Southern Brazilian conditions. It reaches yields of approximately $20 \mathrm{t} / \mathrm{ha}$. Although the cultivation under warm/hot climates may present problems, the cultivar is currently grown in the state of Goiás as an alternative to teinturier grapes.

\subsubsection{BRS Cora}

BRS Cora (Camargo and Maia, 2004) is a high-yield cultivar producing red grapes for juice with excellent colour and high levels of sugar $\left(18-20^{\circ} \mathrm{Brix}\right)$. It is a result of a cross between 'Muscat Bailey A' and BRS Rúbea. It is moderately vigorous, with determinate growth habit. It was released as an alternative to juice and table winemaking in tropical regions to improve the colour of Isabella and Early Isabella products. It can also be grown under temperate climate in South Brazil.

\subsubsection{BRS Violeta}

BRS Violeta (Camargo et al., 2005) is a hybrid grape cultivar, resulting from a cross between BRS Rúbea and IAC 1398-21, that includes V. vinifera and V. labrusca germplasm. It is very fecund (25-30t/ha) and suitable to elaborate juice and table wine. It is adapted to a wide range of climates and can be grown in South Brazil and also in tropical regions, such as the Northwest of the state of São Paulo and Mato Grosso. Its main advantage is the excellent quality of the berries, resulting from the combination of high sugar levels $\left(19^{\circ}\right.$ Brix) and intense violet colour.

\subsubsection{BRS Carmem}

BRS Carmem (Camargo et al., 2008) originated from a cross between Muscat Bailey A and BRS Rúbea. It displays high fecundity, good berry flavour and the must from its grapes is purple in colour. It also shows a good tolerance to the main fungal diseases. Based on evaluation data, the novel cultivar can be recommended for cultivation in Serra Gaúcha and the Northern region of the state of Paraná.

\subsubsection{BRS Magna}

BRS Magna (Ritschel et al., 2012) is also a result from the cross between BRS Rúbea and IAC 1398-21. It is a teinturier grape with labrusca flavour. BRS Magna is a novel cultivar for juice and winemaking with an intermediate productive cycle and wide climatic adaptation. It is recommended to be grown in tropical and temperate climates. It exhibits the typical labrusca or strawberry flavour, resulting in a wine with intense red colour, proper alcoholic grade, and low level of acidity. 


\subsubsection{Concord Clone 30}

Concord Clone 30's (Early Concord) (Camargo et al., 2000) main characteristic is the earliness, since the harvest can be carried out with approximately 15 days of anticipation, in comparison to the harvest dates of traditional Concord. Moreover, Early Concord maintains the features of traditional Concord, mainly its strawberry flavour. Early Concord is recommended to be grown in the south of Brazil, where it can reach yields of $30 \mathrm{t} / \mathrm{ha}$. Currently, its cultivation area is increasing in the region of Bento Gonçalves and in the Western region of Santa Catarina (Camargo, 2008). Based on the performance of the original Concord in tropical regions, the precocious cultivar displays less vigorous growth and poor bud flushing; however, it has the potential to be cultivated in subtropical climates with a single harvest per year (Camargo and Maia, 2008).

\subsubsection{Isabel Precoce (Early Isabella)}

Early Isabella (Camargo, 2004) has the agronomic features of regular Isabella, but presents an early maturation and harvest period of approximately 1 month earlier (Camargo, 2004). As Isabella, it exhibits a typical labrusca or strawberry flavour and can be used to several purposes. Early Isabella is recommended to the south of Brazil. Under warmer climates, such as in the Northwestern of São Paulo, Mato Grosso and Goiás states, Early Isabella is recommended for juice and winemaking, allowing two harvests during the dry season.

\subsection{Future trends}

The continuous enrichment of the grapevine germplasm collection, followed by evaluation and use of the accessions by the Breeding Program, is an important perspective for Brazilian breeding programs. Moreover, these resources are also likely to contribute to the establishment of further Brazilian GIs, such as those of Farroupilha. The sequencing of the Moscato Branco genome will contribute to the development of molecular tools to support further research on grape breeding and genetics in Brazil.

Phenotyping activities are likely to provide tools to meet the future demands of growers and consumers, and new traits will be considered in the forthcoming years, as genotype profiling and evaluation of health-related compounds. Based on SSR molecular marker analysis, coupled with morphological characterization, the classification and identification of accessions will become more precise, and it will result in a better organization and use of the collection. It will also contribute to confirm the nature of Isabella and Concord to their respective sports. Moreover, the evaluation of health-related compounds will allow the development of novel selections appealing to health-oriented consumer markets.

The scenery for the release of novel Brazilian wine grape cultivars in future years is promising, considering the number of hybrids and selections currently under evaluation. Based on the available data, at least one hardy hybrid with Muscat flavour for winemaking will be released in the near future. 


\subsection{Sources of further information and advice}

The vast majority of literature and websites mentioned and commented here are in Portuguese. They are listed in the end of this section.

\subsubsection{The Embrapa grape and wine public page}

This page is in Portuguese, as is the vast majority of the literature and databases and general information; however, a translator may allow recovering the information.

One exception in English is the book 'Embrapa Grape \& Wine - International relations', by Jorge Tonietto and coauthors, which can be downloaded for free and is recommended to those interested in learning more about the research at Embrapa Grape and Wine. It describes the institution history and the facilities (including the laboratory and field researches) and stresses the main technologies, such as a brief description of novel grape cultivars.

Data from Brazilian viticulture can be easily accessed at the Embrapa Grape and Wine page that also hosts the VitisBrasil page. Also on the web, information on the Brazilian GGB and the novel Brazilian grape cultivars are available. Books and papers about current Brazilian viticulture are also present, and the majority can be downloaded for free. 'Vitivinicultura Brasileira - Panorama Setorial em 2010' by José Fernando Protas and Umberto A. Camargo presents a detailed snapshot of the Brazilian grape production and winemaking with data from the main productive regions in the country. In regard to the breeding program at Embrapa Grape and Wine, 'Novas cultivares brasileiras de uvas' by Patricia Ritschel and Sandra Sebben (editors) is available and presents a quick description of the breeding program and a detailed description of novel grape cultivars.

\subsubsection{Books, book chapter and articles}

A very complete panorama of the historical aspects of Brazilian viticulture, remounting the introduction of the grapevine in Brazil, can be found in the books by Julio S. Inglês de Souza, especially 'Uvas para o Brasil’, from 1969.

On the topic of tropical viticulture, 'A viticultura no semiarido brasileiro', by José Monteiro Soares and Patricia C. de S. Leão is recommended. It compiles the research efforts of Embrapa Semiarid and partners over the past 30 years and their contribution to the consolidation of viticulture and the wine industry in the semiarid region of Brazil. Specifically on the development and evolution of tropical viticulture, there is also a chapter about grapes by Patricia Ritschel and coauthors in the first volume of the book 'Agricultura Tropical: quatro décadas de inovações tecnológicas, institucionais e políticas'.

To learn more about the grape breeding program at IAC, one can refer to 'O melhoramento de plantas no Instituto Agronômico' and also to 'Uva: tecnologia de produção, pós-colheita, mercado', by Celso Pommer and coauthors.

A series of papers by Umberto Camargo and coauthors were presented-in 'International Society for Horticultural Science' and in 'Office International de la Vigna et du Vin' meetings and are available, in English, in the Annals of the Events. The evolution of the Brazilian Grape Breeding Programs can be recovered by consulting the documents. 


\section{References}

Alleweldt, G., Spiegel-Roy, P., Reisch, B., 1990. Grapes (Vitis). In: Moore, J.N., Ballington Junior, J.R. (Eds.), Genetic Resources of Temperate Fruit and Nut Crops. The International Society for Horticultural Science, Wageningen, pp. 289-327.

Bennelli, C., de Carlo, A., Engelmann, F., 2013. Recent advances in the cryopreservation of shoot-derived germplasm of economically important fruit trees of Actinidia, Diospyros, Malus, Olea, Prunus, Pyrus and Vitis. Biotechnol. Adv. 31, 175-185.

Bennelli, C., Lambardi, M., Fabbri, A., 2003. Low temperature storage and cryopreservation of the grape rootstock 'Kober 5BB'. Acta Hortic. 623, 249-253.

Börner, A., 2006. Preservation of plant genetic resources in the biotechnology era. Biotechnol. J. 1, 1393-1404.

Camargo, U.A., 1980. Banco ativo de germoplasma de uva. In: Simpósio de Recursos Genéticos Vegetais, Brasília, DF, 1979. EMBRAPA-CENARGEN, Brasília, DF.

Camargo, U.A., 2004. 'Isabel Precoce': alternativa para a vitivinicultura brasileira, vol. 54. Comunicado Técnico (online). Available from: http://www.cnpuv.embrapa.br/pesquisa/ pmu/cultivares.html\#precoce (accessed 03.07.13.).

Camargo, U.A., 1998. Grape breeding for the subtropical and tropical regions of Brazil. In: Symposium International sur la Genetique et L'amelioration de la Vigne, 7, Montpellier, 1998. INRA: Agro-Montpellier, Montpellier.

Camargo, U.A., 2008. Impacto das cultivares brasileiras de uva no mercado interno e potencial no mercado internacional. In: Congresso Brasileiro de Viticultura e Enologia 12, Bento Gonçalves, 2008. Embrapa-CNPUV, Bento Gonçalves.

Camargo, U.A., Bernd, R.B., Revers, L.F., 2009. Melhoramento genético da videira. In: Soares, J.M., Leão, Souza (Eds.), A Vitivinicultura No Semi-árido Brasileiro. Embrapa Semiárido, Petrolina, pp. 109-147.

Camargo, U.A., Maia, J.D.G., Machado, C.A.E., Ritschel, P., 2012a. Evaluation of grapevine germplasm under tropical conditions in Brazil. In: International Crop Science Congress 6, Bento Gonçalves, 2012. International Crop Science Society, Bento Gonçalves.

Camargo, U.A., 2005. Suco de uva: matéria-prima para produtos de qualidade e competividade. In: Congresso Latino-Americano de Viticultura e Enologia 10, Bento Gonçalves, 2005. Embrapa Uva e Vinho, Bento Gonçalves.

Camargo, U.A., Dias, M.F., 1999. BRS Rúbea, vol. 33. Comunicado Técnico (online). Available from: http://www.cnpuv.embrapa.br/pesquisa/pmu/cultivares.html\#rubea (accessed 03.07.13.).

Camargo, U.A., Guerra, C.C., 2001. 'BRS Lorena' : cultivar para elaboração de vinhos aromáticos, vol. 39. Comunicado Técnico (online). Available from: http://www.cnpuv.embrapa.br/ pesquisa/pmu/cultivares.html\#lorena (accessed 03.07.13.).

Camargo, U.A., 2002. Novas cultivares de videira para vinho, suco e mesa. In: Simpósio Mineiro de Viticultura e Enologia 1, Andradas, MG, 2002. EPAMIG, Caldas.

Camargo, U.A., Guerra, C.C., 2007. 'BRS Margot': nova cultivar de uva para vinho tinto, vol. 73. Comunicado Técnico (online). Available from: http://www.cnpuv.embrapa. br/pesquisa/pmu/cultivares.html\#margot (accessed 03.07.13.).

Camargo, U.A., Kunh, G.B., Czermainski, A.B.C., 2000. 'Concord Clone 30' - uva precoce para suco. In: Congresso Brasileiro De Fruticultura 16, Fortaleza. Embrapa Agroindústria Tropical, Fortaleza.

Camargo, U.A., Maia, J.D.G., 2008. Cultivares de uvas rústicas para regiões tropicais e subtropicais. In: Uvas Rústicas de Mesa, Cultivo e Processamento em Regiões Tropicais. Jales, pp. 63-90. 
Camargo, U.A., Maia, J.D.G., 2004. 'BRS Cora': nova cultivar de uva para suco, adaptada a climas tropicais, vol. 53. Comunicado Técnico (online). Available from: http://www. cnpuv.embrapa.br/pesquisa/pmu/cultivares.html\#cora (accessed 03.07.13.).

Camargo, U.A., Maia, J.D.G., Nachtigal, J.C., 2005. 'BRS Violeta': nova cultivar de uva para suco e vinho de mesa, vol. 63. Comunicado Técnico (online). Available from: http://www. cnpuv.embrapa.br/pesquisa/pmu/cultivares.html\#violeta (accessed 03.07.13.).

Camargo, U.A., Maia, J.D.G., Revers, L.F., Leão, P.C. De S., Quecini, V., Ferreira, M.E., Ritschel, P.S., 2012b. Grape genetics and breeding in Brazil. In: XV Congreso Latinoamericano de Genética, Rosário, 2012. Buenos Aires: Journal of Basic and Applied Genetics.

Camargo, U.A., Maia, J.D.G., Ritschel, P.S., 2008. 'BRS Carmem': nova cultivar de uva tardia para suco, vol. 84. Comunicado Técnico (online). Available from: http://www.cnpuv. embrapa.br/pesquisa/pmu/cultivares.html\#carmem (accessed 03.07.13.).

Camargo, U.A., Tonietto, J., Hoffmann, A., 2012c. Progressos na viticultura brasileira. Revista Brasileira de Fruticultura 144-149 Volume Especial.

Camargo, U.A., Zanus, M.C., 1997. EMBRAPA 131-'Moscato Embrapa': nova cultivar para a elaboração de vinho branco, vol. 24. Comunicado Técnico (online). Available from: http://www.cnpuv.embrapa.br/pesquisa/pmu/cultivares.html\#moscatoembrapa (accessed 03.07.13.).

Caumo, M., Galzer, C., Dalagnol, L., Poloni, T., Perissutti, G., Maia, J.D.G., Ritschel, P., 2012. Avaliação do potencial funcional em uvas tintas e rosadas mantidas no Banco Ativo de Germoplasma de Uva. In: Encontro de Iniciação Científica 10; Encontro de Pós-Graduandos da Embrapa Uva e Vinho 6, Bento Gonçalves, 2012. Embrapa Uva e Vinho, Bento Gonçalves.

Dall'agnol, L., Caumo, M., Poloni, T., Comachio, V., Camargo, U., Maia, J.D.G., Ritschel, P., 2013. Características do mosto e de compostos relacionados à saúde de acessos mantidos pelo Banco de Germoplasma de Uva (BAG-Uva). In: Encontro de Iniciação Científica, 11; Encontro de Pós-Graduandos da Embrapa Uva e Vinho 7, Bento Gonçalves, 2013. Embrapa Uva e Vinho, Bento Gonçalves.

Dickenson, J., 1995. Viticulture in pre-independence Brazil. J. Wine Res. 6, 195-200.

Embrapa Uva e Vinho, 2009. Banco Ativo de Germoplasma de Uva (online) Embrapa Uva e Vinho, Bento Gonçalves. Available from: http://www.cnpuv.embrapa.br/prodserv/ germoplasma (accessed 23.02.13.).

Engelmann, F., 1991. In vitro conservation of tropical plant germplasm: a review. Euphytica 57, 227-243.

FAO, 2013. Statistical Databases - FAOSTAT. FAO, Rome. Available from: http//apps.fao. org/page/collections?subset=agriculture (accessed 19.02.13.).

Ferreira, F.R., Pádua, J.G., 2009. Fruteiras e ornamentais. Embrapa Recursos Genéticos e Biotecnologia, Brasília, DF.

Gallo Neto, C., 2008. Um brinde ao vinho paulista. J. da Unicamp 416, 6. (online). Available from: http://www.unicamp.br/unicamp/unicamp hoje/ju/novembro2008/ju416 pag06.php (accessed 24.06.13.).

Guerra, C.C., Hickel, E.R., Kuhn, G.B., Nachtigal, J.C., Maia, J.D.G., Fráguas, J.C., Vargas, L., Mello, L.M.R. de, Garrido, L. da R., Conceição, M.A.F., Botton, M., Oliveira, O.L.P. de, Sônego, O.R., Naves, R. de L., Soria, S. de J., Camargo, U.A., 2005. Sistema de produção de uvas rústicas para processamento em regiões tropicais do Brasil. Sistemas de Produção, vol. 9, (online). Available from: http://sistemasdeproducao.cnptia.embrapa. br/FontesHTML/Uva/UvasRusticasParaProcessamento/index.htm (accessed 25.02.13.). 
Hedrick, U.P., 1919. Manual of American Grape-Growing. The Macmillan, New York, (online). Available from: http://archive.org/stream/manualofamerican29659gut/29659.txt (accessed 05.02.13.).

Hedrick, U.P., 1908. The Grapes of New York. J. B. Lyon, Albany, (online). Available from: http://archive.org/details/cu31924080184165 (accessed 05.02.13.).

IPGRI, 1997. Descriptors for Grapevine: Vitis spp. IPGRI, UPOV, OIV, Paris.

Johnson, H., 1989. The Story of Wine. Mitchell-Beazley, London.

Li, D.-Z., Pritchard, W., 2009. The science and economics of ex situ plant conservation. Trends Plant Sci. 14, 614-621.

Kuhn, G.B., Melo, G.W., Nachtigal, J.C., Maia, J.D.G., Protas, J.F. Da S., Mello, L.M.R. de, Garrido, L. da R., Conceição, M.A.F., Botton, M., Sônego, O.R., Naves, R. De L., Soria, S. de J., Camargo, U.A., 2003. Cultivo da videira Niágara rosada em regiões tropicais do Brasil. Sistemas de Produção, vol. 5, (online). Available from: http://www.cnpuv.embrapa.br/publica/sprod/UvaNiagaraRosadaRegioesTropicais (acessed 01.03.13.).

Maia, J.D.G., Kuhn, G.B., 2001. Cultivo da Niágara Rosada em áreas tropicais do Brasil. Embrapa Uva e Vinho, Bento Gonçalves.

Martins, A.M., Anjos, L.M. dos, Longhi, P., Maia, J.D.G., Boursiquot, J.-M., Legrand, D., Zanus, M.C., Tonietto, J., Ferreira, M.E., Ritschel, P., 2013. Comparative agronomical, phenological and molecular analyses between the grape variety 'Moscato Branco' and accessions of Brazilian and French Grape Germplasm Banks. In: Simpósio de Genética Molecular de Plantas 4, Bento Gonçalves, 2013. Sociedade Brasileira de Genética, Riberão Preto.

Matsumoto, T., Sakai, A., 2003. Cryopreservation of axillary shoot tips of in vitro-grown grape (Vitis) by a two-step vitrification protocol. Euphytica 131, 299-304.

McGovern, P.E., Mirzoianb, A., Halla, G.R., 2009. Ancient Egyptian herbal wines. Proc. Natl. Acad. Sci. USA 106, 7361-7366.

Mello, L.M.R., Machado, C.A., E. VitiBrasil: dados da vitivinicultura. (online). Available from: http://vitibrasil.cnpuv.embrapa.br (acessed 14.02.13.).

Miranda, F., 2001. Arte \& Vinho. Axcel Books do Brasil, Rio de Janeiro.

Mullins, M.G., Bouquet, A., Williams, L.E., 1992. The grape vine and its relatives. In: Mullins, M.G., Bouquet, A., Williams, L.E. (Eds.), Biology of the Grapevine. Cambridge University, Nova York, pp. 17-36.

Paz, C. da, 1898. Manual Prático Do Viticultor Brasileiro. Imprensa Nacional, Rio de Janeiro.

Pinney, T.A., 1989. History of Wine in America: from the Beginnings to Prohibition. University of California, Los Angeles, (online). Available from: http://ark.cdlib. org/ark:/13030/ft967nb63q (accessed 14.02.13.).

Pommer, C.V., 2009. Melhoramento da Videira. (online). Available from: http://www.iac.sp.gov. $\mathrm{br} /$ UniPesquisa/Fruta/Melhoramento/Videira.asp (accessed 25.11.09.).

Pommer, C.V., 1993. Uva. In: Furlani, A.M.C., Viegas, G.P. (Eds.), O melhoramento de plantas no Instituto Agronômico. Instituto Agronômico, Campinas, pp. 489-524.

Protas, J.F. da S., Camargo, U.A., Mello, L.M.R. de, 2002. A viticultura brasileira: realidade e perspectivas. In: Simpósio Mineiro de Viticultura e Enologia 1, Andradas, 2002. EPAMIG, Andradas.

Protas, J.F.S., Camargo, U.A., 2011. Vitivinicultura brasileira: panorama setorial de 2010 (online) SEBRAE, Brasília, DF. Bento Gonçalves: IBRAVIN: Embrapa Uva e Vinho. Available from: http://www.cnpuv.embrapa.br/publica/livro (accessed 14.07.13.). 
Regina, M. de A., Fráguas, J.C., Alvarenga, A.A., Souza, C.R. de, Amorim, D.A. de, Mota, R.V. da, Fávero, A.C., 2006. Implantação e manejo do vinhedo para produção de vinhos de qualidade. Informe Agropecuário 27, 16-31.

Ritschel, P., Camargo, U.A., Mello, L.M.R., Leão, P.C. de S., Soares, J.M., 2008. Uva. In: Albuquerque, A.C.,S., Silva, A.G. da (Eds.), Agricultura Tropical: quatro décadas de inovações tecnológicas, institucionais e políticas, 1, Produção e produtividade agrícola, pp. 537-543.

Ritschel, P.S., Gomes, F.G.G., Ceriotti, I., Longhi, P., Maia, J.D.G., Zanus, M.C., Tonietto, J., Ferreira, M.E., 2012. Genetic analysis of Moscato Branco and other Muscat grapes held by the grape germplasm bank in Brazil. In: International Crop Science Congress 6, Bento Gonçalves, 2012. International Crop Science Society, Bento Gonçalves.

Ritschel, P.S., Maia, J.D.G., (coord.), 2009. Uvas do Brasil: Programa de Melhoramento Genético. (online). Available from: http://www.cnpuv.embrapa.br/pesquisa/pmu (accessed 24.02.13.).

Ritschel, P.S., Maia, J.D.G., Camargo, U.A., Zanus, M.C., Souza, R.T., Fajardo, T.V.M., 2012. 'BRS Magna': nova cultivar de uva para suco com ampla adaptação climática, vol. 125. Comunicado Técnico (online). Available from: http://www.cnpuv.embrapa.br/ pesquisa/pmu/cultivares.html\#magna (accessed 04.07.13.).

Ritschel, P.S., Sebben, S. de S. (Eds.), 2010. Embrapa Uva e Vinho: novas cultivares brasileiras de uva. Embrapa Uva e Vinho, Bento Gonçalves.

Salvador, V. do, 1627. História do Brazil. Biblioteca Nacional, Rio de Janeiro, (online). Available from: http://purl.pt/154 (accessed 14.02.13.).

Santos Neto, J.R.A. (s.d.). Cartilha Do Viticultor. Belo Horizonte: Uvale.

Santos Neto, J.R.A., 1971. O melhoramento da videira no Instituto Agronômico. Ciência e Cultura 23, 700-710.

Soares, J.M., Leão, P. C. de S. (Eds.), 2009. A Viticultura No Semi-árido Brasileiro. Embrapa Semi-árido, Petrolina, PE.

Sousa, J.S.I. de, 1969. Uvas para o Brasil. Melhoramentos, São Paulo.

Sousa, J.S.I. de, Martins, F.P., 2002. Viticultura Brasileira: principais variedades e suas características. FEALQ, Piracicaba.

Terra, M.M., Pires, E.J.P., Coelho, S.M.B.M., Passos, I.R. da S., Santos, R.R. dos, Pommer, C.V., Silva, A.C.P. da, Ribeiro, I.J.A., 1990. Porta-enxertos para o cultivar máximo iac 138-22 de uvas de vinho em Monte Alegre do Sul, SP. Bragantia 49, 363-369.

This, P., Lacombe, T., Thomas, M.R., 2006. Historical origins and genetic diversity of wine grapes. Trends Genet. 22, 511-519.

This, P., Jung, E.A., Boccacci, E., Borrego, E.J., Botta, E.R., Costantini, L., Crespan, E.M., Dangl, E.G.S., Eisenheld, E.C., Ferreira-Monteiro, F., Grando, E.S., Ibañez, E.S., Lacombe, T., Laucou, E.V., Magalhães, E.R., Meredith, C.P., Milani, E.N., Peterlunger, E.E., Regner, E.F., Zulini, L., Maul, E.E., 2004. Development of a standard set of microsatellite reference alleles for identification of grape cultivars. Theor. Appl. Genet. 109, 1448-1458.

Tonietto, J., Hoffmann, A., Zanus, M.C. Embrapa Grape \& Wine - International Relations. Available from: http://www.cnpuv.embrapa.be/publica/livro.

Tonietto, J., 2012. Vale dos Vinhedos and the development of geographical indications in Brazil. In: Worldwide Symposium on Geographical Indications, Lima, 2011. WIPO, Geneva.

Tonietto, J., Mello, L.M.R., 2001. La Quatrième Période Évolutive de la vitiviniculture brésilienne: changements dans le marché consommateur du pays. In: 26 Congreso Mundial \& 81 Asamblea General de la Organización Internacional de la Viña y el Vino, Adelaida 2001. Organización Internacional de la Viña y el Vino - OIV, Adelaida. 
Volk, G.M., 2010. Applications of functional genomics and proteomics to plant cryopreservation. Curr. Genomics 11, 24-29.

Walters, C., Volk, G.M., Richards, C.M., 2008. Genebanks in the post-genomic age: emerging roles and anticipated uses. Biodiversity $9,68-71$.

Wang, Q., Mawassi, M., Li, P., Gafny, R., Sela, I., Tanne, E., 2003. Elimination of grapevine virus A (GVA) by cryopreservation of in vitro-grown shoot tips of Vitis vinifera L. Plant Sci. 165, 321-327.

Wang, Q., Tanne, E., Arav, A., Gafny, R., 2000. Cryopreservation of in vitro-grown shoot tips of grapevine by encapsulation-dehydration. Plant Cell, Tissue Organ Cult. 63, 41-46. 